\title{
PENGARUH PEMAKAIAN MULSA PLASTIK HITAM PERAK DAN APLIKASI DOSIS ZEOLIT PADA PERTUMBUHAN DAN HASIL TANAMAN RADISH (Raphanus satufus L.)
}

\author{
Khaira S. Annisa, Azlina H. Bakrie, Yohannes C. Ginting \& Kuswanta F. Hidayat \\ Jurusan Agroteknologi, Fakultas Pertanian Universitas Lampung \\ Jl. Prof. Soemantri Brodjonegoro, No. 1, Bandar Lampung 35145 \\ E-mail: Khairasofaanisa@gmail.com
}

\begin{abstract}
ABSTRAK
Pertumbuhan dan perkembangan umbi radish sangat dipengaruhi oleh kondisi lingkungan mikro (suhu dan kelembaban) dan ketersediaan unsur hara. Salah satu modifikasi suhu dan kelembaban lingkungan perakaran tanaman dapat dilakukan dengan penggunaan mulsa. Secara fisik mulsa mampu menjaga suhu tanah lebih stabil dan mempertahankan kelembaban di sekitar perakaran tanaman. Cara untuk meningkatkan ketersedian unsur hara adalah dengan memberikan zeolit. Zeolit telah dimanfaatkan di dalam bidang pertanian sebagai menjaga $\mathrm{pH}$ tanah, meningkatkan aerasi tanah, dan efektif untuk pertukaran kation sehingga menjadi pengontrol dalam pembebasan ion amonium, nitrogen, dan kalium serta dapat menetralkan tanah yang bersifat asam mengurangi fiksasi $\mathrm{P}$ dan koloid tanah dan meningkatkan aktivitas mikroorganisme dalam tanah. Penelitian ini bertujuan untuk mengetahui apakah penggunaan mulsa plastik hitam perak berpengaruh positif terhadap pertumbuhan dan hasil tanaman radish, mengetahui berapa dosis zeolit yang menghasilkan pertumbuhan dan hasil tanaman radish yang terbaik, dan mengetahui apakah penggaruh penggunaan mulsa plastik hitam perak terhadap pertumbuhan dan hasil tanaman radish bergantung pada dosis zeolit. Penelitian ini dilaksanakan di laboraturium Lapang Terpadu Fakultas Pertanian Universitas Lampung, Kota Bandar Lampung pada bulan Juli hingga September 2012. Hasil penelitian menunjukkan bahwa aplikasi mulsa memberikan respons/hasil yang lebih baik dibandingkan dengan tanpa mulsa untuk tanaman radish, pada peubah bobot kering brangkasan, dan bobot basah umbi, respons tanaman radish terhadap aplikasi dosis zeolit sampai dosis $800 \mathrm{~g} \mathrm{~m}^{-2}$ masih liniear, dan perlakuan tanpa mulsa dan tanpa zeolit menghasilkan produksi lebih tinggi 52,61 \% (1.027,42 g) daripada dengan menggunakan mulsa (486,84 g). Sedangkan pada zeolit $200 \mathrm{~g}$ $\mathrm{m}^{-2}$ produksi umbi dengan menggunakan mulsa lebih tinggi $81,50 \%(1.299,94 \mathrm{~g})$ daripada tanpa menggunakan mulsa $(716,22 \mathrm{~g})$.
\end{abstract}

Kata kunci: Mulsa, radish, respons, suhu, zeolit.

\section{PENDAHULUAN}

Radish (Raphanus sativus L) merupakan salah satu tanaman perdu semusim yang berumbi; jika dibandingkan dengan sayuran berumbi yang lain, misalnya wortel (Daucus carota $\mathrm{L}$ ) dan ketela rambat (Ipomoea batatas. Poir), penanaman radish di Indonesia belum begitu meluas. Sentra tanaman radish baru di jumpai di daerah Cipanas, Cianjur, Lembang, dan Brastagi. Menurut Sutomo (2009), kandungan nutrisi radish sangat kaya mineral kalsium dan fosfor. Selain itu, radish juga kaya dengan serat dan zat fitonutrien yang baik untuk kesehatan. Oleh karena itu, radish dapat digunakan sebagai obat untuk gangguan ginjal, demam dan obat batuk.

Menurut Kementerian Pertanian (2010), jumlah produksi tanaman radish pada tahun 2009 mencapai 11.940.075 ton dengan luas areal tanaman radish di
Indonesia 15.700 ha. Hal tersebut bisa disebabkan tempat pembudidayaan tanaman radish yang masih sedikit hanya terdapat pada dataran tinggi saja. Sebagai syarat tumbuh, radish sangat cocok pada daerah yang temperaturnya rendah, yaitu $15-22^{\circ} \mathrm{C}$. Tinggi rendahnya temperatur sekitar akan berpengaruh terhadap warna dan bentuk umbi yang dihasilkan. Bila temperatur terlalu rendah maka umbi yang dihasilkan bentuknya memanjang dengan warna pucat. Menurut Nonnecke (1989), jika selama perkembangan umbi terjadi cekaman suhu yang tinggi, umbi yang dihasilkan akan berbentuk abnormal karena terjadi pertumbuhan baru dari umbi yang telah terbentuk sebelumnya yang disebut pertumbuhan sekunder (retakan-retakan pada umbi, pemanjangan bagian ujung umbi, dan kadang-kadang terjadinya rangkaian umbi).

Salah satu modifikasi lingkungan perakaran tanaman dapat dilakukan dengan penggunaan mulsa. 
Mulsa memiliki berbagai keuntungan, baik dari aspek fisik maupun kimia tanah. Secara fisik mulsa mampu menjaga suhu tanah lebih stabil dan mampu mempertahankan kelembaban di sekitar perakaran tanaman. Efek aplikasi mulsa ditentukan oleh jenis bahan mulsa (Bareisis dan Viselga, 2002). Menurut Lamont (1993), penggunaan mulsa anorganik dapat memperbaiki tata udara tanah dan juga tesedianya air bagi tanaman, meningkatkan hasil per satuan luas, efisien dalam penggunaan pupuk, mengurangi erosi akibat hujan dan angin, mengurangi serangan hama dan penyakit tanaman, menghambat pertumbuhan gulma dan mencegah pemadatan tanah.

Zeolit merupakan mineral yang bermuatan negatif, yang dapat dinetralkan oleh logam-logam alkali atau lakali tanah seperti $\mathrm{Na}^{+}, \mathrm{K}^{+}, \mathrm{Ca}^{2+}$ dan $\mathrm{Mg}^{2+}$. Mineral zeolit bersifat basa sehingga dapat menetralkan tanah yang bersifat asam, mengurangi daya fiksasi $\mathrm{P}$ oleh koloid tanah dan meningkatkan KTK serta aktivitas mikroorganisme dalam tanah. Mineral zeolit merupakan bahan yang sangat efektif untuk pertukaran kation

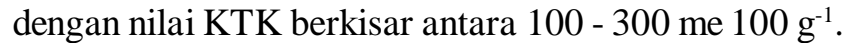
Nilai KTK zeolit tersebut hampir sama dengan KTK

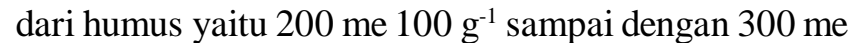
$100 \mathrm{~g}^{-1}$ (Bachrein et al., 1998). Menurut Mumpton (1999), dengan menggunakan zeolit klinoptilolit sebagai pelembab tanah (soil conditioner) akan meningkatkan produksi gandum (13 - 15\%), terong (19-55\%), apel (13-38\%), dan wortel (63\%). Kebutuhan zeolit untuk tanaman bawang, bawang putih, bawang daun, seledri, dan wortel 150 - $300 \mathrm{~kg} \mathrm{ha}^{-1}$.

Penelitian ini bertujuan untuk mengetahui pengaruh mulsa plastik hitam perak pada pertumbuhan dan hasil tanaman radish, mengetahui berapa dosis zeolit yang menghasilkan pertumbuhan dan hasil tanaman radish yang terbaik, dan mengetahui apakah mulsa plastik hitam perak mempengaruhi dosis zeolit dalam meningkatkan pertumbuhan dan hasil tanaman radish.

\section{BAHAN DAN METODE}

Penelitian ini dilakukan di laboratorium Lapangan Terpadu Fakultas Pertanian Universitas Lampung yang pada bulan Juli-September 2012. Alat-alat yang digunakan untuk kegiatan penelitian ini adalah cangkul, koret, gembor, ember, meteran, mistar, nampan plastik, gunting, cutter, timbangan dan alat tulis. Bahan yang akan digunakan dalam penelitian adalah benih radish (Raphanus sativus L.) varietas Purple Top Milan, pupuk kandang kotoran kambing, urea, $\mathrm{KNO}_{3}$ mulsa plastik hitam perak dan zeolit. Rancangan perlakuan disusun secara faktorial (5×2). Faktor pertama adalah tanpa menggunakan mulsa $\left(\mathrm{M}_{0}\right)$ dan menggunakan mulsa plastik hitam perak $\left(\mathrm{M}_{1}\right)$. Faktor kedua adalah pemberian dosis zeolit yang terdiri dari 5 taraf yaitu 0 $\mathrm{g} \mathrm{m}^{-2}\left(Z_{0}\right), 200 \mathrm{~g} \mathrm{~m}^{-2}\left(Z_{1}\right), 400 \mathrm{~g} \mathrm{~m}^{-2}\left(Z_{2}\right), 600 \mathrm{~g} \mathrm{~m}^{-2}\left(Z_{3}\right)$, $800\left(Z_{4}\right) \mathrm{g} \mathrm{m}^{-2}$. Rancangan lingkungan yang digunakan adalah Rancangan Kelompok Teracak Sempurna (RKTS) dengan tiga ulangan. Keragaman data diuji dengan uji Bartlett dan sifat kemenambahan data diuji dengan uji Tukey. Data diolah dengan analisis ragam, dilanjutkan dengan uji Polinomial Orthogonal dan ortogonal Kontras. Semua pengujian dilakukan pada taraf nyata $5 \%$ atau $1 \%$.

Lahan digemburkan dan dibuat bedengan dengan ukuran $1 \mathrm{~m}$ x 1,5 m sebanyak 30 yang dibagi menjadi tiga ulangan. Lahan diberikan pupuk kandang kambing dengan takaran $2 \mathrm{~kg}$ petak $^{-1}$ dan zeolit yang sudah ditimbang sesuai perlakuan dan diberakan selama 4 hari. Pupuk dasar Urea, $\mathrm{KCl}$ dan SP 36 diberikan secara bersamaan dengan cara ditabur dengan dosis masingmasing $20 \mathrm{~g}_{\text {petak }}{ }^{-1}, 10 \mathrm{~g}_{\text {petak }}^{-1}$, dan $30 \mathrm{~g}_{\text {petak }}{ }^{-1}$. Pemasangan mulsa dilakukan setelah aplikasi pupuk, baru dilakukan pembuatan lubang tanam dengan jarak tanam $10 \mathrm{~cm}$ x $20 \mathrm{~cm}$, dan jumlah tanaman per petak sebanyak 24 tanaman. Pemeliharaan tanaman meliputi pengairan atau penyiraman, pembumbunan, penyiangan tumbuhan pengganggu, dan pemberantasan hama penyakit. Panen dilakukan 50 hari setelah tanam.

Untuk menguji kerangka pemikiran dan hipotesis dilakukan pengamatan terhadap komponen pertumbuhan dan produksi. Setiap petak percobaan diambil lima sampel tanaman. Variabel pengamatan meliputi peubah yaitu jumlah daun tanaman dihitung dengan satuan lembar, bobot basah umbi radish diukur dengan satuan gram, bobot kering brangkasan diukur dengan satuan gram, diameter umbi radish diukur dengan $\mathrm{cm}$, volume umbi radish diukur dengan satuan $\mathrm{mm}$, dan produksi tanaman per petak diukur dengan gram.

\section{HASIL DAN PEMBAHASAN}

Hasil penelitian menunjukkan bahwa pemberian zeolit berpengaruh positif terhadap peubah jumlah daun dan bobot kering brangkasan (Tabel 1, Gambar 1, dan Gambar 2) diameter umbi, volume umbi, bobot basah dan produksi per petak (Tabel 2, 3 dan Gambar 3-6).

Menurut Suwardi (2006), fungsi zeolit adalah sebagai pemantap tanah (soil conditioner), bahan pembenah tanah (soil amendment), pembawa unsur pupuk, sebagai slow release fertilizer dan menjaga kelembaban tanah. Tanah yang ditambah zeolit unsur hara yang ada di dalam tanah menjadi lebih efisien diserap oleh tanaman dan secara fisik akar tanaman 
Tabel 1. Pengaruh mulsa dan dosis zeolit terhadap jumlah daun radish. dan bobot kering brangkasan.

\begin{tabular}{|c|c|c|c|c|c|c|c|c|}
\hline \multirow{2}{*}{ Perlakuan } & \multicolumn{2}{|c|}{ Selisih } & \multirow{2}{*}{ F-hit } & \multirow{2}{*}{ Sig. } & \multicolumn{2}{|c|}{ Selisih } & \multirow{2}{*}{ F-hit } & \multirow{2}{*}{ Sig. } \\
\hline & JD (lbr) & $\%$ & & & $\mathrm{BKB}(\mathrm{g})$ & $\%$ & & \\
\hline Mulsa (M) & & & & & & & & \\
\hline $\mathrm{C}_{1}$ : tanpa mulsa vs mulsa & -2.72 & -7.11 & 1.91 & tn & -0.136 & -14.87 & 8.46 & $* *$ \\
\hline ZEOLIT (Z) & & & & & & & & \\
\hline $\mathrm{C}_{2}$ : Z-Linier & & & 11.98 & $* *$ & & & 10.34 & $* *$ \\
\hline $\mathrm{C}_{3}$ : Z-Kuadratik & & & 3.82 & tn & & & 7.41 & $*$ \\
\hline Interaksi (M x Z) & & & & & & & & \\
\hline $\mathrm{C}_{4}: \mathrm{C}_{1} \times \mathrm{C}_{2}$ & & & 0.54 & tn & & & 2.28 & tn \\
\hline $\mathrm{C}_{5}: \mathrm{C}_{1} \times \mathrm{C}_{3}$ & & & 0.14 & tn & & & 0.71 & tn \\
\hline
\end{tabular}

Keterangan : JD = jumlah daun (lembar), BKB = bobot kering berangkas, F-hit $=$ F hitung, Sig $=$ Signifikansi. $\operatorname{tn}=$ tidak nyata dan $*=$ nyata berdasarkan uji $\mathrm{F}$ pada $\alpha_{0,05} *^{*}=$ nyata berdasarkan uji $\mathrm{F}$ pada $\alpha_{0,01}$.

Tabel 2. Pengaruh mulsa dan dosis zeolit terhadap bobot basah umbi, diameter umbi dan volume umbi.

\begin{tabular}{|c|c|c|c|c|c|c|c|c|c|c|c|c|}
\hline \multirow{2}{*}{ Perlakuan } & \multicolumn{2}{|c|}{ SBB } & \multirow{2}{*}{ F- hit } & \multirow{2}{*}{ Sig } & \multicolumn{2}{|c|}{ SDU } & \multirow{2}{*}{ F- hit } & \multirow{2}{*}{ Sig } & \multicolumn{2}{|c|}{ SVU } & \multirow{2}{*}{ F- hit } & \multirow{2}{*}{ Sig } \\
\hline & $\mathrm{g}$ & $\%$ & & & $\mathrm{~g}$ & $\%$ & & & $\mathrm{ml}$ & $\%$ & & \\
\hline \multicolumn{13}{|l|}{ Mulsa (M) } \\
\hline $\mathrm{C}_{1}: \mathrm{M}_{0}$ vs $\mathrm{M}_{1}$ & $-269,6$ & $-59,7$ & 19,6 & $* *$ & $-3,2$ & $-8,4$ & 9,5 & tn & $-17,2$ & $-8,7$ & 1,6 & tn \\
\hline \multicolumn{13}{|l|}{ ZEOLIT (Z) } \\
\hline $\mathrm{C}_{2}$ : Z-Linier & & & 6,7 & $*$ & & & 12,2 & $* *$ & & & 36,5 & $* *$ \\
\hline $\mathrm{C}_{3}$ : Z-Kuadratik & & & 0,1 & tn & & & 9,7 & tn & & & 7,5 & $*$ \\
\hline \multicolumn{13}{|l|}{ Interaksi (M x K) } \\
\hline $\mathrm{C}_{4}: \mathrm{C}_{1} \times \mathrm{C}_{2}$ & & & 0,3 & tn & & & 1,8 & tn & & & 0,06 & $\operatorname{tn}$ \\
\hline $\mathrm{C}_{5}: \mathrm{C}_{1} \times \mathrm{C}_{3}$ & & & 0,5 & $\operatorname{tn}$ & & & 0,6 & tn & & & 0,10 & tn \\
\hline
\end{tabular}

Keterangan: $\mathrm{M}_{0}=$ tanpa mulsa, $\mathrm{M}_{1}=$ dengan mulsa, $\mathrm{SBB}=$ selisih bobot basah, $\mathrm{SDU}=$ selisis diameter umbi, $\mathrm{SVU}=$ selisis volume umbi, F-hit $=\mathrm{F}$ hitung, $\mathrm{Sig}=$ signifikasi. $\mathrm{tn}=$ tidak nyata dan $*=$ nyata berdasarkan uji $\mathrm{F}$ pada $\alpha_{0,05}{ }^{* *}=$ nyata berdasarkan uji $\mathrm{F}$ pada $\alpha_{0,01}$.

berkembang optimal. Hal ini yang menyebabkan jumlah daun, diameter umbi, volume umbi, bobot basah umbi, dan bobot kering brangkasan pada pemberian zeolit lebih tinggi dibandingkan tanpa zeolit. Hasil ini sejalan dengan penelitian tentang manfaat zeolit yang dilakukan Estianty (2005), menunjukkan bahwa penambahan zeolit pada media tanam dapat meningkatkan jumlah basa-basa $\mathrm{K}$, $\mathrm{Na}, \mathrm{Ca}$ dan Mg serta meningkatkan KTK tanah.

Pada percobaan ini, pemakaian mulsa plastik hitam perak berpengaruh nyata pada peubah bobot basah umbi, bobot kering brangkasan, dan produksi per petak (Tabel 1 - 3). Hal ini disebabkan peran mulsa sebagai pengatur iklim mikro khususnya terhadap intersepsi radiasi oleh tanaman dan suhu tanaman. Menurut hasil penelitian Zainal (2004), pada mulsa plastik hitam perak memiliki intersepsi radiasi oleh tanaman, pemantulan radiasi matahari oleh mulsa yang lebih tinggi dan suhu tanah lebih rendah. Hal ini dapat dimanfaatkan untuk meningkatkan aktivitas akar dalam menyerap unsur hara dalam tanah serta mengurangi laju repsirasi. Kedua hal tersebut dapat berpengaruh terhadap hasil produksi yang meningkat. Lamont (1993), menyebutkan bahwa mulsa plastik bukan hanya meningkatkan produksi saja akan tetapi dapat mempercepat umur panen, pengendalian gulma, meningkatkan efisiensi penggunaan air dan pupuk.

Pada variabel peubah jumlah daun, diameter umbi, dan volume umbi perlakuan pemakaian mulsa tidak berbeda nyata dengan perlakuan tanpa menggunakan mulsa. Hal ini diduga fotosintat yang dihasilkan dari proses metabolisme tanaman sebagian besar ditranslokasikan dan digunakan dalam penambahan bobot basah umbi, bobot kering brangkasan, dan produksi umbi. Dari perlakuan dosis zeolit dan pemakaian mulsa plastik hitam perak menunjukkan adanya interaksi pada 
Tabel 3. Tanggapan tanaman pada produksi umbi radish per petak terhadap pemakaian mulsa dan aplikasi dosis zeolit.

\begin{tabular}{|c|c|c|c|c|}
\hline \multirow{2}{*}{ Perlakuan } & \multicolumn{2}{|l|}{ Selisih } & \multirow{2}{*}{ F- hitung } & \multirow{2}{*}{ Signifikansi } \\
\hline & Produksi per petak (g) & $\%$ & & \\
\hline \multicolumn{5}{|l|}{ Mulsa (M) } \\
\hline $\mathrm{C}_{1}: \mathrm{M}_{0}$ vs. $\mathrm{M}_{1}$ & 217,54 & 3,35 & 0,29 & $* *$ \\
\hline \multicolumn{5}{|l|}{ Zeolit (Z) } \\
\hline $\mathrm{C}_{2}: \mathrm{Z}$-Linier & & & 12,59 & $* *$ \\
\hline $\mathrm{C}_{3}:$ Z-Kuadratik & & & 3,85 & $* *$ \\
\hline \multicolumn{5}{|l|}{ Interaksi (M x Z) } \\
\hline $\mathrm{C}_{4}: \mathrm{C}_{1} \times \mathrm{C}_{2}$ & & & 0,31 & $* *$ \\
\hline$C_{5}: C_{1} \times C_{3}$ & & & 1,07 & $* *$ \\
\hline \multicolumn{5}{|c|}{ Tanggapan terhadap m pada } \\
\hline $\mathrm{Z}_{0}: \mathrm{M}_{0}$ vs $\mathrm{M}_{1}$ & 540,55 & 52,61 & 2,85 & $* *$ \\
\hline $\mathrm{Z}_{1}: \mathrm{M}_{0}$ vs $\mathrm{M}_{1}$ & $-583,71$ & $-81,50$ & 2,07 & $* *$ \\
\hline $\mathrm{Z}_{2}: \mathrm{M}_{0}$ vs $\mathrm{M}_{1}$ & 545,45 & 34,35 & 1,36 & $* *$ \\
\hline $\mathrm{Z}_{3}: \mathrm{M}_{0}$ vs $\mathrm{M}_{1}$ & $-591,36$ & $-35,65$ & 0,37 & $* *$ \\
\hline $\mathrm{Z}_{4}: \mathrm{M}_{0} \mathrm{vs}_{1}$ & 306,61 & 20,46 & 0,16 & $* *$ \\
\hline \multicolumn{5}{|c|}{ Tanggapan terhadap z pada } \\
\hline $\mathrm{M}_{0}:$ Z-Linier & & & 4,48 & $* *$ \\
\hline $\mathrm{M}_{0}$ : Z-Kuadratik & & & 0,43 & $* *$ \\
\hline $\mathrm{M}_{1}: \mathrm{Z}$-Linier & & & 8,41 & $* *$ \\
\hline $\mathrm{M}_{1}$ : Z-Kuadratik & & & 4,50 & $* *$ \\
\hline
\end{tabular}

Keterangan : $\mathrm{M}_{0}=$ tanpa mulsa, $\mathrm{M}_{1}=$ dengan mulsa, $\mathrm{Z}_{0}=$ tanpa zeolit, $\mathrm{Z}_{1}=$ zeolit $200 \mathrm{~g} \mathrm{~m}^{-2}, \mathrm{Z}_{2}=$ zeolit $400 \mathrm{~g} \mathrm{~m}^{-2}$, $\mathrm{Z}_{3}=$ zeolit $600 \mathrm{~g} \mathrm{~m}^{-2}, \mathrm{Z}_{4}=$ zeolit $800 \mathrm{~g} \mathrm{~m}^{-2}$. th $=$ tidak nyata dan $*=$ nyata berdasarkan uji $\mathrm{F}$ pada $\alpha_{0,05}$. ** = nyata berdasarkan uji $\mathrm{F}$ pada $\alpha_{0,01}$.

peubah produksi per petak. Pada perlakuan tanpa mulsa peningkatan $100 \mathrm{~g} \mathrm{~m}^{-2}$ zeolit meningkatkan bobot produksi $1,57 \mathrm{~g} / 1,5 \mathrm{~m}^{2}$ bobot sedangkan pada perlakuan mulsa setiap penambahan $100 \mathrm{~g} \mathrm{~m}^{-2}$ zeolit meningkatkan bobot produksi radish $1,97 \mathrm{~g} \mathrm{~m}^{-2}$. Hasil penelitian menunjukkan bahwa pada dosis zeolit $0 \mathrm{~g} \mathrm{~m}^{-2}$, penggunaan mulsa menghasilkan produksi umbi yang lebih rendah dibandingkan tanpa menggunakan mulsa $(52,61 \%)$. Akan tetapi pada dosis zeolit $200 \mathrm{~g} \mathrm{~m}^{-2}$ menghasilkan produksi dengan selisih terbesar. Ratarata produksi per petak untuk tanpa mulsa yaitu 716,22 $\mathrm{g} / 1,5 \mathrm{~m}^{2}$ sedangkan yang menggunakan mulsa menunjukkan hasil produksi per petak yaitu sebesar $1.299,94 \mathrm{~g} / 1,5 \mathrm{~m}^{2}(81,50 \%)$. Hal ini diduga karena mulsa mempengaruhi suhu tanah karena suhu tanah sangat tergantung pada proses penukaran panas antara tanah dengan lingkungannya. Proses tersebut terjadi akibat adanya radiasi matahari dan pengalirannya ke dalam tanah lebih sedikit dibandingkan tanah tanpa mulsa dan penambahan zeolit dapat memperbaiki agregasi tanah sehingga meningkatkan pori-pori udara tanah yang berakibat merangsang pertumbuhan akar tanaman.

Ditinjau dari hasil penelitian yang telah dilakukan dan membandingkan dengan hasil peneliti lain menunjukkan bahwa dosis zeolit $200 \mathrm{~g} \mathrm{~m}^{-2}$ dapat meningkatkan hasil lebih tinggi dibandingkan dengan 150 - $300 \mathrm{~kg} \mathrm{~m}^{-2}$. Hal ini sama dengan yang di laporkan Prihatini et al., (1987) bahwa zeolit sebagai pembenah tanah dengan takaran $\geq 1.000 \mathrm{ppm}$ atau $\geq 2$ ton ha ${ }^{-1}$ dapat meningkatkan KTK tanah mineral masam dan selain itu zeolit mampu menyerap air dan mengadsorpsi ion $\mathrm{NH}_{4}^{+}$, yang sewaktu-waktu dapat dilepas secara perlahan saat tanaman memerlukan, sehingga ion $\mathrm{NH}_{4}^{+}$ tidak hilang tercuci dan akibatnya efisiensi penggunaan pupuk $\mathrm{N}$ meningkat. Potensi hasil umbi radish per hektar sekitar 40 ton ha ${ }^{-1}$ atau $40 \mathrm{~kg} \mathrm{~m}^{-2}$. Apabila dibandingkan 


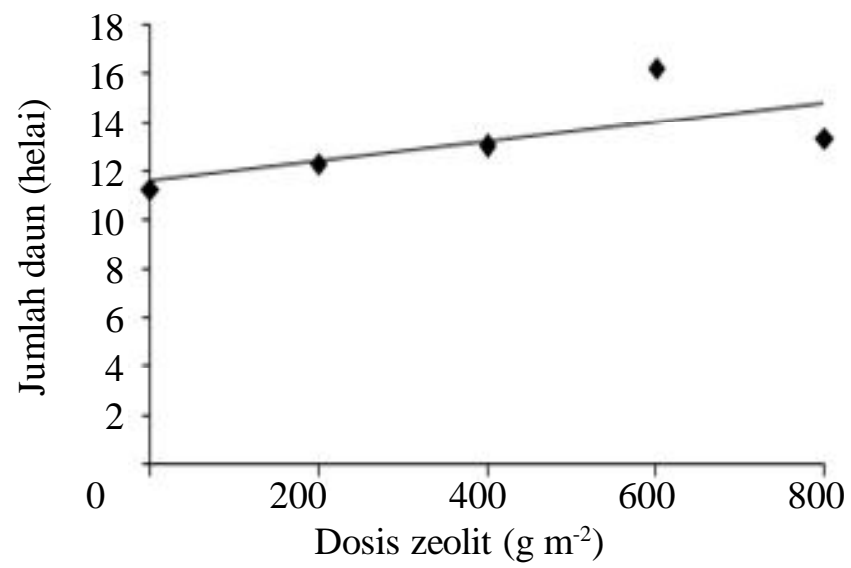

Gambar 1. Hubungan antara dosis zeolit dengan peningkatan jumlah daun radish : $\mathrm{y}=$ $0,0004 x+11,607 ; r=0,682$.

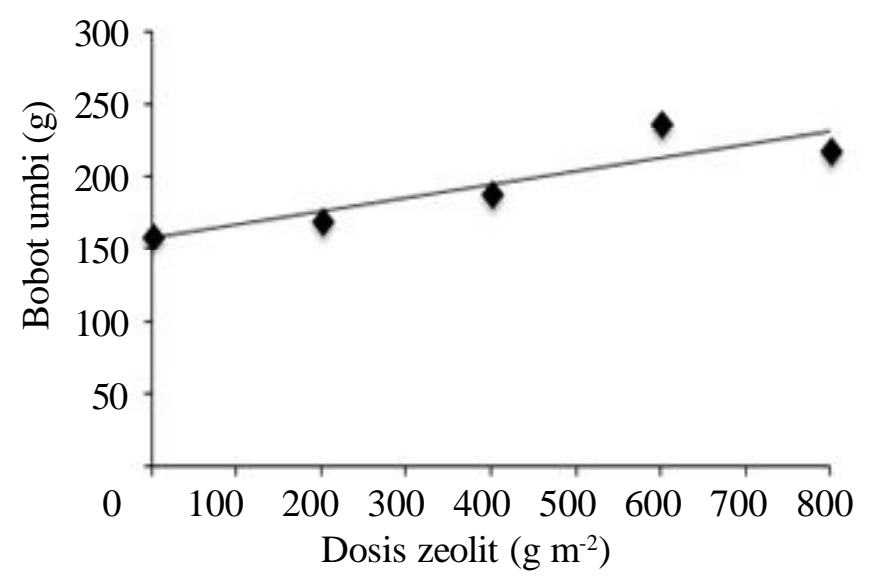

Gambar 3. Hubungan antara dosis zeolit dengan peningkatan bobot basah umbi : $\mathrm{y}=0,093 \mathrm{x}$ $+158,3 ; r=0,896$.

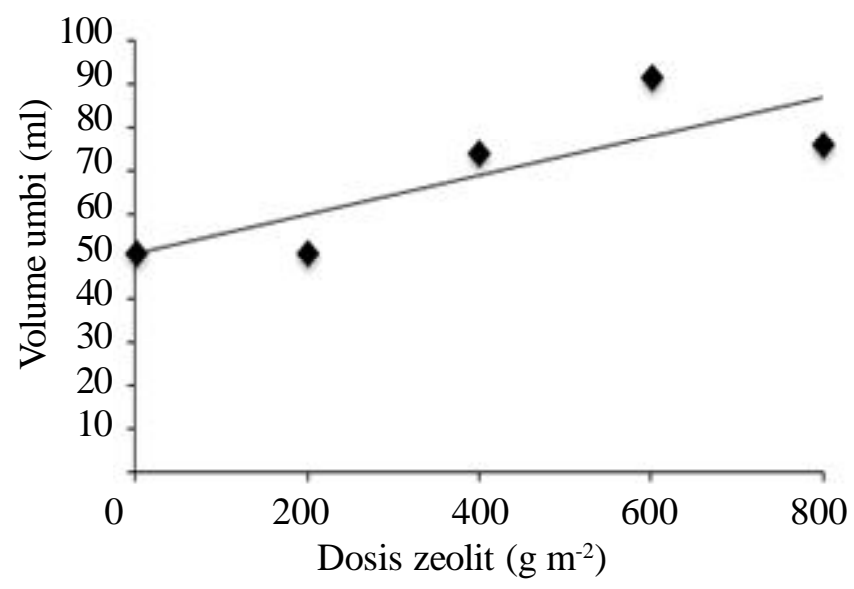

Gambar 5. Hubungan antara dosis zeolit dengan volume umbi radish : $\mathrm{y}=0,0455 \mathrm{x}+50,733 ; \mathrm{r}=$ 0,819 .

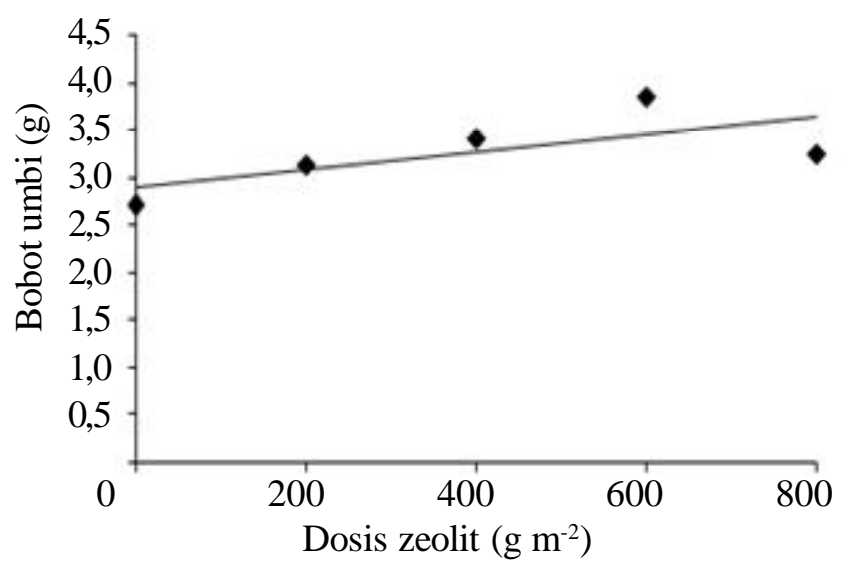

Gambar 2. Hubungan antara dosis zeolit dengan peningkatan bobot kering brangkasan : $\mathrm{y}=$ $0,0009 x+2,9117 ; r=0,684$.

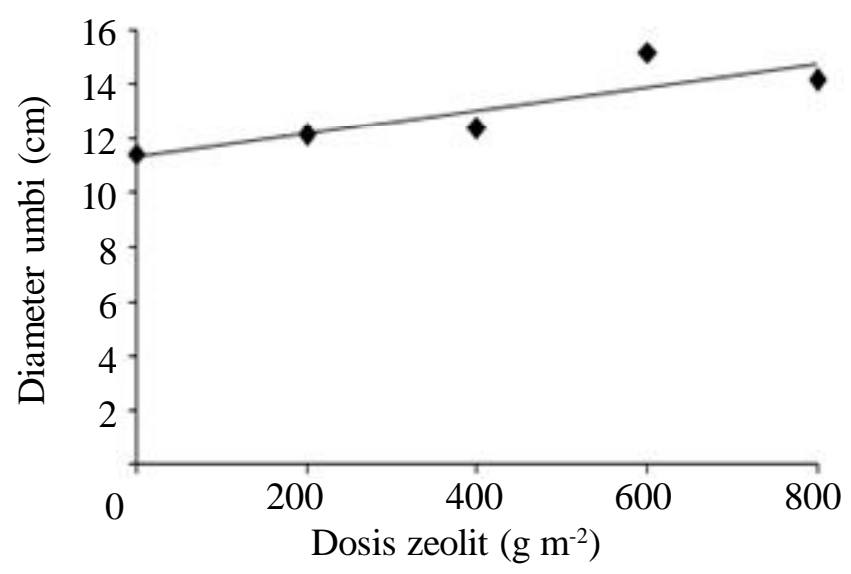

Gambar 4. Hubungan antara dosis zeolit dengan diameter umbi radish : $\mathrm{y}=0,0043 \mathrm{x}+11,373 ; \mathrm{r}=$ 0,863 .

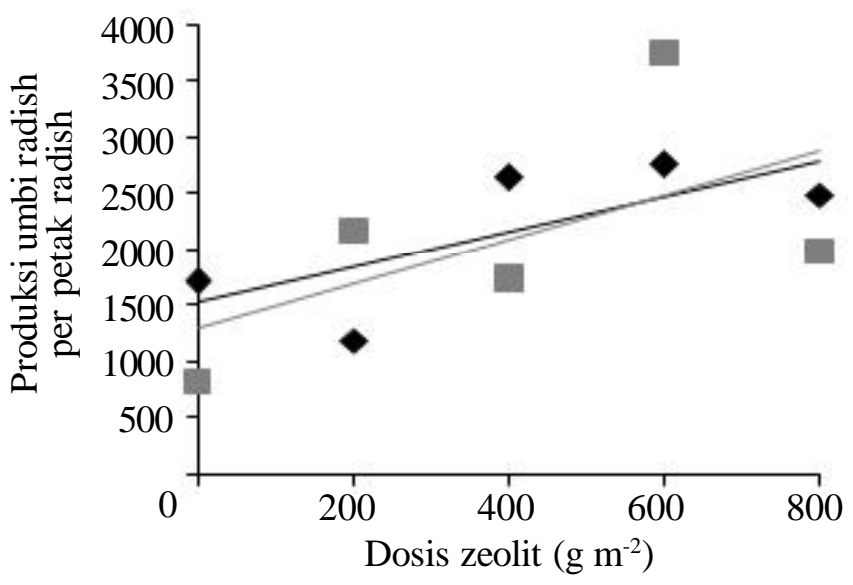

Gambar 6. Hubungan antara dosis zeolit dengan produksi umbi radish per petak radish pada perlakuan mulsa plastik dan tanpa mulsa. $\square=\mathrm{m}_{0}$ (tanpa mulsa), $\diamond=\mathrm{m}_{1}$ (dengan mulsa). 
dengan hasil penelitian menunjukkan bahwa hasil penelitian ini masih di bawah potensi hasil. Hal ini mungkin disebabkan oleh faktor-faktor yang ada di lingkungan penelitian seperti kondisi tanah yang kurang baik dan suhu yang tidak cocok dengan tanaman radish.

\section{KESIMPULAN}

Adapun kesimpulan yang dapat ditarik dari penelitian ini adalah aplikasi mulsa memberikan respons/ hasil yang lebih baik dibandingkan dengan tanpa mulsa untuk tanaman radish, terutama pada peubah bobot kering brangkasan, dan bobot basah umbi dan produksi per petak. Respons tanaman radish terhadap aplikasi dosis zeolit sampai dosis $800 \mathrm{~g} \mathrm{~m}^{-2}$ masih liniear. Perlakuan tanpa mulsa dan tanpa zeolit menghasilkan produksi lebih tinggi 52,61\% (1.027,42 g) daripada dengan menggunakan mulsa $(486,84 \mathrm{~g})$. Sedangkan pada zeolit $200 \mathrm{~g} \mathrm{~m}^{-2}$ produksi umbi dengan menggunakan mulsa lebih tinggi $81,50 \%$ (1.299,94 g) dari pada tanpa menggunakan mulsa $(716,22 \mathrm{~g})$.

\section{DAFTAR PUSTAKA}

Bachrein, S., N.S. Dimyati, dan A. Dimyati. 1998. Pengkajian Mineral Zeolit Zeo Agro G super pada tanaman padi sawah tadah Hujan dan Berpengairan. Makalah disajikan pada Seminar Sehari Bimas, Departemen Pertanian. Jakarta, 8 Juli 1998. Bimas. Jakarta. 68 hlm.

Bareisis R., G. dan Viselga. 2002. Trends in the development of potato cultivation technologies. Institute of Agricultural Enginering, Raudonddevaris. $65 \mathrm{hlm}$.
Estiaty, L.M. 2005. Pengaruh Zeolit Terhadap Media Tanam.http://www.chemis.try.org/ artikel_kimia/kimia_material/ pengaruh_zeolit_terhadap_media_tanam/ html. Diakses pada tanggal 10 Januari 2012.

Kementerian Pertanian. 2010. Hortikultura (Profil Tanaman Pangan dan Hortikultura). Jakarta. http://www.deptan.go.id. Diakses pada tanggal 24 Januari 2012.

Lamont, W.J. 1993. Plastic Mulches for The Production of Vegetable Crops. Hort Technology. 3(1) : 3539.

Mumpton, F. A. 1999. Uses of natural zeolites in agriculture and industry. Proc. Natl. Acad. Sci. USA. Vol. 96, pp. 3463-3470.

Nonnecke, Ib. L. 1989. Vegetable Production. Van Nostrand Reinhold. New York. 657 hlm.

Prihatini, T., S. Moersidi, dan A. Hamid. 1987. Pengaruh zeolit terhadap sifat tanah dan hasil tanaman. Pemberitaan Penelitian Tanah dan Pupuk. Pusat Penelitian Tanah. Badan Litbang Pertanian. (7) $: 5-8$.

Sutomo, B. 2009. Lobak. http://id.wikipedia.org/ wiki/lobak. Diakses pada tanggal 29 Oktober 2011.

Suwardi. 2006. Penggunaan Zeolit Di Bidang Pertanian. Prosiding Seminar Nasional Zeolit $V$. Bandar Lampung. $30-39 \mathrm{hlm}$.

Zainal, E. 2004. Efek Penggunaan Berbagai Warna Mulsa Plastik pada Iklim Mikro, Ukuran Umbi dan Produksi Tanaman Kentang Var. Granola (Solanum Fuberosum L.). Institut Pertanian Bogor, Bogor. 